\title{
COMING HOME TO EUROPE TRAVELS AND TRAVAILS IN A LOST CONTINENT
}

\section{ULLRICH KOCKEL}

The notion of European visions, visions of Europe, or indeed 'Eurovisions', has been popular for some time. Shrouded in a mist of discourse, this Europe is now almost unknowable. This essay explores ways of knowing Europe through its debatable lands in the relationship between Heimat and frontier. Keywords: Celtic Fringe, Central Europe, frontier, Heimat, heritage, Iron curtain, Sarmatia, sense of place.
Zamisel o "evropskih vizijah», "vizijah Evrope« ali »evrovizijah« je popularna že nekaj časa. Zakrita v mešanici diskurzov je ta Evropa skoraj nepoznana. Avtor razkriva načine spoznavanja Evrope stališca spornih ozemelj v razmerju med Heimat - domovino in mejo.

Ključne besede: keltski rob, srednja Evropa, meja, domovi$n a$, dedišcina, železna zavesa, občutek prostora.

Every journey has to start from somewhere and one of the journeys to Europe started with the project to a-peace two quarrelsome neighbors, France and Germany. Historically, one of the causes for their frequent disputes appears to lie under ground: the coal and steel resources of Alsace-Lorraine and the Saarland. To settle these disputes, the Treaty of Paris in 1951 created a European Coal and Steel Community. The Treaty of Rome in 1957 established its better known partner, the European Economic Community. To win the hearts and minds of the people who, until not so long ago, had been whipped into hating each other, popular culture was marshaled. The arsenal included popular TV-shows, such as Jeux Sans Frontières, a fun-and-games competition involving teams from different European countries that started life in France as Intervilles, running internationally from 1965, in Germany under the title Spiel ohne Grenzen, as Eurovision-broadcast organized by the Italian company RAI. A year earlier, the federation of German regional broadcasting companies had launched its 'great international quiz', moderated by the highly popular actor Hans-Joachim Kulenkampff. This Saturday prime-time show should run for well over twenty years, until 1987, making it one of the most successful, longest-running programmes on German television. Its title was Einer wird gewinnen, ${ }^{1}$ which can be abbreviated as 'EWG', and this, in German, is also the abbreviation of the European Economic Community.

1 The title translates as 'Someone will win', or 'There will be one winner'. The Minister for School and Further Education in North Rhine-Westphalia, Barbara Sommer, reminisced in a Newsletter issued in connection with Germany's EU Presidency in 2007 that Einer wird gewinnen 'focused on Europe and presented Europe as a fascinating cultural area with cross-border opportunities for personal development.' Like many in the first post-War generation, she thus 'gained the conviction that a united Europe reinforces and promotes cultural and economic interests' (www.europa.nrw.de/newsletter/ 


\section{THE LOST CONTINENT}

Europe - but where is it? There was a place called 'Europe' once. Until not all that long ago, it seemed to be a fairly obvious matter where and what this Europe was (cf. Kockel 1999: 15-44). The Danes saw it as the area between their province of Sønderjylland and the Dolomite mountains in northern Italy; to the English it was a barbarian realm beyond the home of their Norman colonizers; for the Russians it was a kind of cultural Alter Ego. The French and Germans would expect Europe to be a place where at last they might live together in peace. And some incurable romantics regarded Kakania, the Austro-Hungarian monarchy, as the prototype for a multi-cultural 'Europe'. While it did mean different things to different people, there was consensus that it did exist somewhere - a consensus that evaporated in the final decades of the twentieth century as the constructivists and deconstructionists disposed of Europe through discourse. Deconstructionists revealed our familiar ideas and philosophical approaches as shamefully Eurocentric. I am not sure whether anyone dared to ask how they possibly could be if there was no such thing as 'Europe' in the first place, but this might have been an unfashionable comment to make in the circumstances. 'Eurobashing' had become a well established intellectual ritual. According to the constructivists, Europe, like everything else, is invented, typically by powerful political interests or by everyone else's 'false consciousness.'

There are, of course, various visions of Europe, and each of these rests on its own set of premises. The notion of European visions, visions of Europe, or indeed 'Eurovisions', has been popular for some time now. Since my 2001 inaugural at the University of the West of England, Bristol (Kockel 2003a), it has served as label for a youth competition in Germany (Behnke 2006); a project of politico-cultural networking championed by the Goethe-Institut and culminating in a conference at Berlin's Kronprinzenpalais in 2004 (www.goethe.de/ins/vb/prj/euro/); a disappointingly patchy survey of 'good Europeans' (Frevert 2003); and, a series of short films commissioned to mark the eastern enlargement of the European Union (Europäische Visionen 2004), to name but a few recent examples. As the medieval historian Michael Borgolte points out, any historical representation of Europe is a construct that will only hold if you accept its premises (Borgolte 2005: 124). Whether you buy into this argument depends less on whether or not there is a Europe, or what it looks like, than on whether you are an idealist or a realist at heart - not just philosophically speaking. Arguably, Europe can be easily overlooked on a rapidly spinning globe. As the Irish literary critic Declan Kiberd (2005: 255) has observed, "to the Japanese Europe now appears as a tiny, open-air boutique at the fag-end of Asia." In this light, the growing interest in Eurasia in Anglophone social anthropology is perhaps not surprising, although why 'Eurasia' should be regarded as any less of a construct than 'Europe' remains

nlfebruar07_web_de.html; accessed 7 February 2008; the name of the presenter is misspelled in the Newsletter). 
a puzzle. Already some two and a half millennia ago, the Greek historiographer Herodotus criticized the conceptual division of the known world of his day into three Continents, because he saw Europe, Asia and Libya (that is: Africa) as a single landmass.

In certain ways, due to its colonial expansion in the past, Europe is everywhere. Its colonial past is one reason for the negative image Europe has acquired in academic and popular perception in recent decades, an image frequently invoked in proposals to accelerate its conceptual demise. And yet, it is sometimes said that one person's colonizer may be another person's entrepreneur. Peripheral regions, often referred to as internal colonies, know a thing or two about this dilemma. Its history of colonization and migration has meant that Europe, be it invented or not, has become increasingly difficult to delineate. In this situation, some old conceptual boundaries may be revived. Elias Canetti wrote in his autobiography that people in his native village on the lower Danube referred to people who went up the river to Vienna as someone who was "going to Europe. Europe began where the Turkish Empire had once ended" (Canetti 1999: 5). A century later, Europe is being defined once again (or still) in contradistinction to Islam. At a time when the European Union has just acquired its first indigenous Muslim minority, in its new member state of Bulgaria, and Turkey itself is applying to join the Union, this makes less sense than ever. Creating Europe has always been, as the Lithuanian poet Thomas Venclova (2006: 242) points out, a task full of uncertainty and risk.

But what is the point of it all? Did not Europe, if it every lived, die long ago? One hears this diagnosis frequently, usually attributed to the break-up of the Austro-Hungarian Empire or, more often, the Holocaust. In either case, the reference to Europe is in fact to a 'Central European' culture, perceived as characterizing what in an Irish translation of an essay by Milan Kundera is called Croí na hEorpa, 'heart of Europe' (Kundera 1990). While nostalgia for the Golden Age of the Habsburg monarchy may appear in some texts addressing the question of Central Europe, most authors have a more differentiated view of the region and its history than critics from outside give them credit for (Kockel 1999: 52-60). The debate about Central Europe is going through cycles of vibrancy and dormancy. Since around the time of the 'Eastern enlargement' of the EU we seem to witness one of the former, in which German attempts at coming to terms with the rediscovery of lost territories are playing a noticeable part. The identity of the region tends to be closely associated with its shtetl culture. The extinction of this culture in the Holocaust is recognized - not just by academics and popular writers hailing from elsewhere but, more importantly, also in the poetry and prose of authors from the region, such as Johannes Bobrowski or Czesław Miłosz - as a major factor in the destruction of (Central) Europe as a specific historical context. The horror of the Holocaust is terrible proof that, whatever the constructivists say, Europe is emphatically not a mere invention. To pronounce Europe dead because of it amounts to a refusal to engage with the dark side of European cultural heritages.

The homepage of the Berlin-based company Europäischer Austausch gGmbH, founded in 2005, which works with NGOs in Eastern Europe, especially in Belarus und 
Ukraine, quotes Susan Sontag's suggestion that Europe may be far from dead: "It may be truer to say that Europe has yet to be born" (www.european-exchange.org). In a later essay on the idea of Europe, Sontag argues, however, that the territory Europe now occupies is ever shrinking, and that 'increasing numbers of its citizens and adherents will understand themselves as émigrés, exiles, and foreigners' - strangers in our own land (Sontag 2003: 289). There is more than a grain of truth in this analysis. Europe does exist, even if late or post-modernity has successfully dismantled our cozy certainties. Shrouded in a mist of discourse, this Europe is now almost unknowable. It has become a non-place. So, how should we approach this non-place, how can we find and explore different visions of it? More to the point, how will we know whether what we find and see has anything to do with Europe at all? Such is the epistemological quagmire that we have allowed ourselves to be led into by all that discourse. The only analysis permitted is one that dissects precisely how a particular construct has been constructed, by whom and for what. Everything else is decried as essentialism. If we dared to ask the constructivists how and why they construct the forces that allegedly construct everything, the infinite regress of their approach might become only too evident.

\section{HEIMAT AND HERITAGE}

Following on from my earlier explorations of the ethnic frontiers of European integration (Kockel 1999), I suggested at the 2004 conference of the European Association of Social Anthropologists in Vienna that one possible way of approaching questions of European identities and boundaries may be to examine whether and to what extent Europe can be considered as being built by people who dwell in the frontier created by EU integration. The terms 'building' and 'dwelling' have obvious resonances. Heidegger's philosophical word-play with the terms constructing and cultivating - the German word bauen can mean both - suggests a link of the cultural with the political that is pragmatic rather than metaphysical. At the same time, however, the particular link implied, between place, being and longing, points, via an English word-play in a Heideggerian spirit, towards the metaphysics of belonging - to 'be longing' as a general human condition - that can be expressed in the act of dwelling (wohnen) as inhabiting (bewohnen) a place or space in a way that invests the location with shared meanings, which over time become the habits (Gewohnheiten) of its inhabitants (Bewohner). These habits, as traditions and heritage, are then available as both repertoire and backdrop for auto- and heterological representations of identity (Kockel 2007: 85-101). The latter have the 'Other' as their 'target audience' and project a public image whereas the former are directed towards the Self and serve to affirm one's roots, imagined or otherwise. Elsewhere I have developed the contrast of territory and trajectory (Kockel 1999: 290 ff.). 'Territory' hardly needs clarification - its meaning as 'bounded area ruled by a particular power' is fairly widely employed. 'Trajectory' has 
its root in the Latin verb traicere, going across, and tends to be used to describe transgression, transition, or carrying across a distance, usually incorporating the overcoming of an obstacle. I have been using the term to denote the 'life-paths' (of individuals and groups) that link up significant places and/or events (Kockel 2005).

Another key term here is 'frontier'. In the academic literature as well as in EU policy discourse, the term is commonly used as synonymous to and interchangeable with boundary and border. In this confused, sloppy usage, the analytical potential of language is sacrificed. Etymologically, 'frontier' can be related to 'in front of': that which lies ahead, between the subject and his or her horizon. Therefore everywhere outside the Self, and as far as the individual world-version stretches, is the 'frontier', which thus forms an essential part of Self-identification. Whereas territory is about spatial identity, and territorial space is defined by boundaries, the frontier can be seen as an indeterminate, open space. I have introduced the German term Fremde as translation of 'frontier' as a means of analyzing the relationship between the Self and the 'Other'. The frontier in this sense is outside one's own personal space, but nevertheless located within a familiar horizon - otherwise it could not be recognized as such, and could not serve as a parameter of belonging.

It is worth emphasizing the implications of this use of terms. The character of the frontier (Fremdheit) is determined - in the dual sense of that term - within the Self. If something or someone is experienced as befremdlich (strange), that is not the same as unbekannt (unknown); rather, it means that the person or object has already entered the familiar horizon and is within sight (and potentially, one may speculatively pun, with insight), forming part of the Self's world. Ontologically the inevitable conclusion is that the Self is at the centre of the frontier (das Zentrum der Fremde ist das Eigene) and that the frontier emanates from the Self into the world (geht vom Eigenen aus in die Welt hinein). Thus by dwelling in the frontier and cultivating it, the inhabitants make it habitable and thereby gradually convert it into their own. This is the untranslatable, utopian place called Heimat, which is conditional on the frontier (Fremde) as the horizon within which it can be experienced. Without the frontier, as at once its frame of reference and its counterpoint, the idea of Heimat makes little sense. Moreover, the frontier serves as a kind of 'ante-room' for the Self - an 'Other' may be safely translated into the familiar frontier, and thus brought closer without actually being granted access into one's Heimat, thereby remaining fremd until he or she ceases to be unheimlich (uncanny) and perhaps even becomes heimisch (settled). If there is a Heimat Europa out there somewhere, it therefore makes sense to look for it, and for the Europeans who make it, in the frontier - in open, undefined spaces and along trajectories.

In German-speaking Europe, and to some extent beyond, the matter of Heimat has experienced a discursive boom since at least the 1980s. Despite negative associations, not least with the kitsch cinema and folksy pop music of the post-War economic miracle, the term has always had currency among the undogmatic Left, where Ernst Bloch in the 1950s had postulated it as the key utopian location (Bloch 1978). Regionalist movements and, 
from the 1970s onwards, environmentalists appropriated the term as imbued with positive values, and often juxtaposed it to the hegemony as a subversive principle (Kockel 2003b). At the broader societal level, the Heimat debate gathered momentum with the screening of Edgar Reitz's eponymous family epic in the late 1980s. This coincided with the entirely unplanned end of the Communist regime in the German Democratic Republic and the subsequent, equally unplanned unification of Germany, which gave the debate a new direction. Since then, the debate has continued with a stream of articles, pamphlets and books (e.g.: Krockow 1992; Schmidt B. 1994; Hecht 2000; Schlink 2000; Türcke 2006).

The English-speaking world simultaneously experienced a similar debate, albeit its focus was somewhat different. That debate centered on the matter of heritage and its role in contemporary society. Like the Heimat debate, it has had links with regionalism, and it also has had its subversive fringe. But by and large it has had two more pragmatic foci, perhaps reflecting the well-rehearsed (e.g., Lepenies 2006) contrasts between a civilized transatlantic world and a cultured but stuck-in-the mud continental Europe. One of these foci, which overlap to some extent, has been on the commercial utilization of heritage and all the concomitant problems; the other has been on issues of authenticity, legitimacy and the ownership of heritage (Nic Craith and Kockel 2007). Like the Heimat debate, the heritage debate has been fuelled by and revolved around issues of belonging to and alienation from regionally grounded (in a semi-literal sense) culture contexts. The materiality of these contexts has been hotly contested, not least in the course of the 'invention of tradition' debate that has led many protagonists to proclaim the inauthenticity of traditions on the basis that they are invented.

Despite the logical fallacy of such claims, constructivist interpretations of the world are enjoying considerable popularity in academic discourse and beyond. This is not the place to engage in epistemological and ontological analysis, but it should be noted that it is irrelevant whether heritage and tradition are invented or communities imagined - if they have actuality, that is, if they shape the immediate and wider habitat, their reality is generated in the process, and it therefore does not have to be a factum a priori in order to be valid. If we consider as 'traditional' and 'genuine' only those ideas and practices that were concocted by only God knows who, and at a time well beyond the horizon of memory (and preferably of written history), then we commit the fallacy of a shallow essentialism equating age, measured in geological proportions, with veracity and legitimacy and denying these qualities to any creative act in more recent times. We need better criteria for establishing what is or is not an authentic tradition. 'Authentic' does not mean 'exclusive' or 'exclusionist'. 'Traditional' does not mean 'good and valuable by definition'; not all traditions are worth having, but the distinction is a matter of ethical judgment rather than ontological certainty. Moreover, the historical dimension of belonging that is highlighted

2 Dictionary/thesaurus definitions of 'authentic' include: valid, bona fide, reliable, dependable, realistic, accurate, faithful. There is no suggestion of exclusivity here; that suggestion is an addition the term has acquired in certain politically motivated discourses, including some putatively academic ones. 
by the concept of tradition must be ecologically embedded; our past is always a past in its place, the place we come from - even when 'coming from' already implies that we are no longer there.

\section{IN SEARCH OF EUROPE}

There is a common perception that the place we come from is what we call 'home' - or, as I prefer to say: Heimat. Yet this Heimat may also be located in a utopian future - a "Not Yet" kind of place, to be brought into existence through the creative acts of a liberated humanity (Bloch 1978). This is not the going home of the postmodern individual who, like Anglo-European settlers in America, is always on the move to somewhere else, 'seeking out the next horizon, finding Eden in some other locale and ultimately in glory above' (Deffenbaugh 2006: 5). It is more the coming home as understood by Native Americans who stress the need "to achieve a very clear intuition of what it means to live with integrity right where they are". This 'coming home' may be referred to as the transformation of the world into Heimat - investing a particular world version with patterns of meaning generating authentic belonging and, perhaps, even a sense of community that at once grounds and transcends any individual identity (Kockel 2003b). In terms of the analytical framework outlined earlier, Heimat becomes a place that we are (habitually) used to, replete with markers of our habits. One could say that we can wrap ourselves in a place as if in a cloak (or habit) for protection against the elements. Let us look at some places that people have become wrapped up in, to see whether and what kind of 'Europe' may be found there. Having spent more than half my life at or near what is often controversially referred to as the Celtic Fringe, it seems appropriate to start these explorations from here.

\section{THE CELTIC FRINGE}

Historically, the term 'debatable lands' designates areas of disputed sovereignty along the Anglo-Scottish border. Used in the plural, 'debatable lands' refers to any part of the border held to be doubtful; in the singular it usually refers to the area in the west, between the Rivers Esk and Sark, where the border agreed in 1552 is marked on modern maps as the 'Scots Dyke'. The term 'Scots Dyke' has been used in recent years in various geographical and metaphorical senses by writers and singers. A significant observation in regard to the Celtic Fringe is that most outsiders would not consider this region part of that Fringe. However, historically and culturally, this area is every bit as much a heartland of Celticity as the Highlands and Islands with their Norse Viking cultural overlay. Strathclyde and Cumbria may have been Brythonic rather than Goidelic, and may have become 'hybridized' sooner and/or differently than other parts of the islands. But that does not take from their significance for the image of a Celtic World that stretched across the Western seaboard 
of Europe. King Arthur may have been a Romanized Cumbrian P-Celt leading a band of Sarmatian horsemen against the Saxons, as a recent movie suggests, or he may have been a post-Roman mythic incarnation of the Q-Celt Fionn MacCumhail. Either way, we should not lose sight of the fact that Keltoi was a term liberally applied by the ancient Greeks to just about anyone living north of their own realm and who was not in the habit of speaking proper Greek. It seems more appropriate to think of 'non-Classical' Europe when we are looking for inspiration in 'the presuppositions of an old Europe' (Biggs no date: 71). A 'non-Classical' Old Europe stretches eastward from the Celtic Fringe as far as Europe goes (at least), and includes those parts where, according to some accounts, King Arthur's horsemen hailed from.

\section{SARMATIA}

Sarmatia is one of the lost provinces of Europe; at one time it was its centre. Located between Lithuania, Belarus, Ukraine and Poland, Sarmatia saw Joseph Roth reach for his pen, Czesław Miłosz stroll around its markets and fairs, and the Singers and Brodskys pack their cases - if they had time to do so. It was the dreamland of Johannes Bobrowski, the wild realm where all peoples and religions could find their place, had not History ploughed under everything time and time again. Martin Pollack invited twenty-five writers to speak about Sarmatia, to remember it and to explore the fault lines of its landscape. The result is a compendium of a lost land, the rediscovery of which could give Europe a different, more open name. ${ }^{3}$

Inseparably connected, as the names cited in the blurb for a collection of essays (Pollack 2005) suggest, with the shtetl culture of eastern central Europe, Sarmatia was and is a wider region, and a debatable land. Large parts of it are, in the vernacular language, simply called 'in the frontier' (U Kraina). On some old maps, Sarmatia more or less coincides with the Polish-Lithuanian Commonwealth at its territorial peak, and is divided by Muskovy into a south-eastern or 'Asian' and a north-western or 'European' part, while other cartographic representations are less ambitious: The 1593 map by de Jode depicts it as Prussia and the adjacent forest wildernesses to the east and south. Speculations about Arthurian horsemen and the potential origin of the possibly Pictish queen Guinevere among Finno-Ugric tribes of Sarmatia - or indeed the steppes beyond - point to connections across Old Europe that are as intriguing as their twentieth-century equivalents, from the German Youth Movement to the art of Joseph Beuys (Kockel 1995). In the north of Sarmatia, contemporary Lithuania likes to emphasize the fact that it was the last country in Europe to be Christianized. The dates vary, but tend to fall about a thousand years after the date St Patrick

3 This paragraph is my own adapted translation of the cover text of Pollack (2005). 
set foot in Ireland. When the Reformation arrived through traders and colonial powers, it came to a people who had barely begun to adapt the new religion to their old practices. While Lithuania is a Catholic country - its Jewish population largely extinguished by the Holocaust and the Protestant colonizers departed after 1945 - there coexists under a thin veneer of modernity a considerably older Europe.

In 2004, the Franco-German TV company Arte commissioned film makers from every country of the expanded EU to produce short films presenting their country's vision of Europe. Surprisingly many of the entries chose religious, even mythical themes, and virtually all entries played with symbols. Most of them did so from a contemporary, postmodern perspective using conventional forms of exposition, which makes the films accessible for students who are trained in that mould. However, several cohorts of my students have been utterly confounded by the Lithuanian entry (Bartas 2003). The mostly monochrome film shows four children interacting and dreaming with nature, history and place. A frog and a paper boat, both resiliently indestructible, also play a major part. Although I can understand the film intuitively, I find it almost impossible to explain to the students what it says about Europe, except that it represents an altogether different way of looking at the world.

There is another aspect to Sarmatia that I should mention before moving on. Some years ago, after my first visit to Lithuania, I played a new CD on the car stereo. It was a recording produced by the folk choir Vorusnelè from near Klaipeda, the formerly German city of Memel. ${ }^{4}$ Perhaps I should not have been surprised to hear a tune from my childhood - but I was. Many years ago I had learnt it, and loved it, as a song about nature and young love: Zogen einst fünf wilde Schwäne (Five wild swans once flew). The image of the five birch trees standing on the banks of the river Memel (or Nemunas) is forever engraved in my memory. Later I had found out that this was an anti-war song, dating back at least to the Thirty-Years-War in the seventeenth century and probably beyond. The song with its strange harmonies had been popular with the rambling groups of the Youth Movement, both between the two World Wars and after 1945. What the unexpected encounter with the tune on my way to work invoked in me was not so much the fond memory of a childhood favorite, but the realization that I had a bond with Sarmatia that stretched deeper into the twentieth century than my personal life horizon.

After some reflexive searching, I now understand how this bond came about, but the puzzle remains. As far as I know, neither side of my family has any connection with Sarmatia; indeed, neither parent ever so much as visited the region. And yet, both parents were deeply enchanted by the "Land der dunklen Wälder und kristallnen Seen" (land of the dark forests and crystal-clear lakes; the opening line of the regional anthem, the Ostpreußenlied). This much I remember, and while I did not recall any of the stories and songs that must have accompanied this experience, had seen no pictures of it and never had any conscious longing to go there - other than the curiosity of the incurable traveler - I would instantly recognize

4 Track 13: 'Penkios baltos gulbès' (Five white swans), Ten ant Jüračiu (Land by the Sea), Druka, Klaipeda, no date. 
the landscape of north-western Sarmatia as familiar when I visited there for the first time. It was like coming home. Indeed, it felt much more like coming home than returning to any place that I could technically call home ever has done. While I had developed a sense of athome-ness away from my birth region before, not least on the Celtic Fringe in both Ireland and Scotland, in those cases I had arrived with a considerable store of advance knowledge, my imagination fuelled by pictures, songs and stories, and so ready to engage with the place consciously. With Sarmatia, the sequence was uncannily reversed - as, following my first visit there, I started reading texts about and from the region, I recognized images and passages that recollect memories of Dämmerstunde (twilight hour), when around sunset in late autumn my mother would read stories or recite poems by candle light, ballads like Die Frauen von Nidden by Agnes Miegel (Schmidt 1994: 57-58). The second half of this ballad is a dialogue between seven women who survived the Black Death and the Great Dune that rises between the village of Nidden and the Baltic Sea. Partly defiant, partly reconciled to the inevitable cycle of life in this place, the heart of the Curonian Spit, the women invite 'little Mother', as they call the Great Dune, to bury them - 'and the dune came and draped herself over them'. I had completely forgotten the rest of the poem and its context for some forty years or more, except for that last line. What does this tell us about oral tradition, especially where the process of tradition may happen away from the ecological context to which it refers? What does it tell us about Old Europe? What does it tell us about ways in which we inhabit - we dwell in and on - our world? Before pursuing these issues any further, I want to turn to a European frontier that is not on the outer edge, but right in the middle of this sub-continent - the debatable lands of the former Iron Curtain.

\section{ZONENRAND}

In the very north of Bavaria lies the district of Coburg, joint to its mighty southern neighbor by one of the many plebiscites carried out across Europe after the First World War. Had it not been for that plebiscite, I more than likely would not be here: My father, born in Kamenz near Dresden, was discharged from an American POW camp in Bavaria and never crossed the Iron Curtain after that. Much of my early life took place in or near what then used to be called the Zonenrandgebiet, that is, the area where the three joint zones of Allied occupation that made up West Germany bordered on the fourth zone known as East Germany. Until 1973, this was officially referred to as 'Middle Germany', and our school books represented 'Germany in the borders of 1937' - i.e. before the Nazi land-grab started - and the lost territories in the east as 'currently under Polish/Russian administration'. As I have only recently begun to think about this, I will not delve too deeply into the matter, but would like to highlight briefly some aspects that may be of particular interest here.

5 One could say 'covered them' or 'tucked them in', but these literal translations would not capture the spirit of the original in the same way. 
Despite the later image of steel fences, land mines, tank barriers and, of course, the Berlin Wall, the Iron Curtain was for the first third of its existence far less brutal in outward appearance. One abiding memory from early childhood - bare of any wider context as these memories tend to be - is of a visit to a café owned by a school friend of my mother's, located right on the border and aptly named Grenzlandcafé. As we were sitting on the terrace, my father decided to walk over to the barbed wire fence to chat with the farmer working on the other side, and mother called after him: 'You'll get yourself shot!' He didn't. But my curiosity was awakened: Why should anyone get themselves shot for chatting with someone on the other side of a fence?

Images of Sunday walkers gathering on hill tops with binoculars to gaze into the land no longer accessible to them sit alongside images of parcels passed across the fence, always in the same direction: east. And then the wild boar - pictured in the Coburger Tageblatt newspaper - that had one of his legs ripped off by a newly laid landmine. No more chats, and no more parcels - only the lonesome groups with their binoculars on the hilltops. As the border was fortified, viewing towers began to spring up on the western side, civilized equivalents of the grim army watchtowers on the eastern side: the border became a tourist attraction, almost an economic asset. The Zonenrandgebiet, especially after 1961, was an area earmarked for special development funding. Towns cut off from their traditional hinterland struggled to keep economically afloat while the rest of West Germany was enjoying the fruits of the post-War 'economic miracle'. On the other side of the 'inner-German' border, there was a five kilometers wide stretch of land called the Sperrzone (off-limits area); anyone living or working there needed a special permit to do so. In 1952 and 1962, the East German government undertook two operations, code-named, respectively, Ungeziefer (vermin) and Kornblume (corn flower), during which more than 10,000 inhabitants of the Sperrzone were expelled - in official parlance: 'resettled' - from their villages. Well into the 1970s many more of these villages, which were perceived as located too close to the border, were bulldozed.

The border, known as Zonengrenze, was the first element in a multi-layered structure of debatable lands, encompassing the lost territories and 'language islands' in the east, which provided the reference framework for German identity post-1945 on either side of the Iron Curtain. The Zonenrandgebiet was not really part of the everyday post-War experience of the majority of Germans in the West, just like the Sperrzone on the other side was not really part of the everyday post-War East. They were, in an uncanny sort of way, negative exemplars of what Hermann Bausinger has called Binnenexotik - the exotic within. At the same time, these two areas were quintessential for the self-definition of the respective political system, and, at a different level, both played a key role in the popular sense of belonging. Thus the Zonengrenze was a peculiar expression of that "particular paradox of a liminality that both joins and divides" (Biggs no date: 18). Not surprisingly, when the border was finally removed, a number of border museums were created, some of them in situ, others by gathering buildings and other structures in a kind of theme park. 
The border itself, the landmines now cleared, is being turned into a nature reserve and ramblers' paradise - a Scots Dyke for at-home-less Germans.

In the early 1970s, a pocket of West Germany protruding into East Germany along the river Elbe became the site of the only attempt (so far) at secession from the Federal Republic of Germany. Surrounded on three sides by the Iron Curtain, the Wendland seemed an obvious place for the disposal of nuclear waste. The local population saw the matter differently, and their on-going struggle is well documented. On May 3rd, 1980, the Freie Republik Wendland was proclaimed by some 5,000 local inhabitants supported by a 'rainbow' coalition of non-locals from all walks of life and all regions of West Germany. Although bulldozed some weeks later, but the Republic continues to exist, as broadcasts, publications and other grass-roots political actions expressing opposition to the nuclear dump testify. Whether this was a genuine attempt at secession or merely a sophisticated political joke is a moot point. The Republic was a bold statement of local resistance to remote political control. For those not originally from the Wendland, it offered, not least through its passports that are 'valid as long as the bearer can still laugh', a sense of belonging and at-home-ness in a state that many at the time perceived as cold, hostile, and teetering on the brink of the next World War.

\section{CONTRASTING VISIONS OF EUROPE}

From a 'Fortress Europe' envisaged to keep the barbarians of all perceptions firmly outside the gates, to a lost Mitteleuropa imagined as a peaceful melting pot of cultures with a Jewish intellectual class as its cosmopolitan heart, visions of Europe are numerous and very often conflicting. Except for the lost Mitteleuropa, few of these visions acknowledge "those ecological polyphonies - material and imaginal - that found our common oikos ... our ultimate if always uncertain sense of being at home" (Biggs no date: 18). And while he has a lot to say about issues of dwelling and belonging, the loner from Todtnauberg tends to be rather over-cited and under-stood in these debates. But that is a matter for another day.

After Donald Rumsfeld, there is a New Europe and an Old Europe - the former ready to buy into America's mission to save the world from itself, the latter with a mind of its own. It was clear where his preferences lay, and they are not mine. One of the great issues of our time is the displacement of Old Europe - ideologically, politically, and even economically as the American free market does its best to pull the world with it into free fall. In this situation, we would do well to realize the subversive potential of being 'from here'. This relates to the existential ecological grounded-ness referred to earlier. Both historical and contemporary precedence can be found in the debatable lands I have traversed here.

In Sarmatia, this is known by the term tutejsi (spelled or transliterated - from the 
Cyrillic - differently in different regions). ${ }^{6}$ The category first appeared as tutejszy in connection with the Polish census. In 1931, only two 'ethnic' categories were allowed: religious affiliation (wyznanie religijne) and mother tongue (jzyk ojczysty). This was to avoid problems and disputes that had arisen after the 1921 census, when, in response to the nationality question, many non-Poles had been counted as 'Polish' because that was the language they used most regularly. However, a significant majority in the north-eastern region of Polesia had responded to the language question by saying 'own language' (swój język), 'our language' (po naszemu), or 'local' (tutejszy). Those who spoke 'local' comprised some 62.4\% of the inhabitants of Polesia; in official documents and statistics, this group was henceforth described as 'Polesians' (Poleszucy) (Trepte 2004).

At the other end of Sarmatia, in Western Ukraine, the concept has also recently made an appearance. Here it has been explicitly linked with a 'very old', 'quasi-pagan' Europe. In a wide-ranging essay on the crafting of hybrid identities, the Ukrainian intellectual Adrian Ivakhiv asserts paradoxically that:

The most genuinely nomadic ... may be those designated by the simple term tuteishyi, the word for those who are simply 'from here,' even if that 'here' changes in relation to the 'theres' which have shaped and defined the territory ... over its many imperial and political-economic realignments. (Ivakhiv 2006: 38)

The tuteishyi is both homeless and deeply rooted, "placeless in a larger sense, yet rooted enough in his or her own space (Tarasiewicz's forests, Maszlanko's fields), mobile in the tracks and paths carved out through earthy meanderings in the interstices of nations and empires" (Ivakhiv 2006: 38f.). "Dwelling requires homelessness" (Biggs no date: 28). What those who are 'from here' in this sense are saying about their identity is not that each individual human being has many identities (and Heimat places), but that only the multiple forms of expression and definition ${ }^{7}$ taken together make up the respective identity/ Heimat. Where a number of people relate one (identity) or the other (Heimat) or both to the same bioregion, there we may have something like community in the ecological sense (Deffenbaugh 2006; also Kockel 2008).

Oral tradition in cases where the process of tradition happens away from the ecological context it refers to still has relevance for belonging and the imaginal components of our identities. But this obviously is not, cannot be the same relevance as for people coming from a place. Coming home to a place that has not been our own is possible, but what does it mean for our reading of the presuppositions underpinning cultural expressions, old or new? Is there a way of connecting with an Old Europe? If I say that I know there is, I don't mean 'know' in the sense in which we normally use that word. Perhaps a better

6 Tutejsi is the title of a film and community project promoting local traditional culture in the PolishBelorussian borderlands by recording the old songs and stories, carried out in association with the Architecture Laboratory Żywej in Leipzig.

7 'Definition' is understood here in the literal sense of being de finis, 'about boundaries'. 
answer may be found in the praxis by which we make our places habitable. But whom do we have in mind when we do that? Is not all inclusion, whatever its motivation, also a form of exclusion by default? My hunch is that as we delve more deeply into this we need to radically change our binary categories and the corresponding vocabulary before we can expect deeper insights into these issues. As the project of European integration progresses, creating an ever more mobile population of Europeans as a fundamental pre-condition for the smooth functioning of a single European labor market, the ecological grounded-ness of belonging will increasingly depend on its actualization. The detachment, post-modern or otherwise, of belonging and identity from their concrete regional foundations poses a fundamental existential challenge for anthropology. There is a danger that the subject will disappear in a nebulous discourse of construction, invention and imagination that celebrates the alleged inauthenticity of anything and everything cultural, and the consequent nonexistence of any material basis for cultural expressions, including the rug under its own feet. Without wanting to pursue the matter further at this point, it is worth observing that the progressive excision of culture from the anthropological agenda in favor of the more civilized term society echoes the contempt for 'old' Europe expressed by many whose political background and agenda we would do well to remind ourselves of. Anthropology as culture critique does not necessarily mean having to run down culture at every opportunity; a less destructive way of critiquing culture would be by grounding our analysis once again in actual fieldwork conducted in regions understood as meaningful ecological contexts. In doing so, we need to remind ourselves of the original significance of the term regio, which implies the broad reach of a particular hegemony rather than a clearly bounded territory with discrete and unique characteristics. If understood in this sense, regio designates a locational space with boundaries that are somewhat blurred and continuously shifting, rather than neat and clear-cut. Much of our recent conceptual problems with 'regional cultures' may reflect our failure to appreciate this quality of ecological regions, which makes attempts to squeeze cultural expressions into singular categorical and geographical boxes difficult, if not entirely futile. When we find a way out of this dilemma, we may be able to reclaim the displaced land of Europe by re-placing it. This may involve a certain re-orientation - a re-Easting - of what it means to be a European.

\section{REFERENCES}

Bartas, Sharunas (dir.)

2004 Children Loose Nothing. Kinema 2003. DVD absolutmedien. Zentropa.

Behnke, Dina

2006 'Europäische Vision': Creativity Contest for Young People - Closing Ceremony in Berlin. Europe direct Newsletter 5, June, 3. 
Biggs, Iain

no date Volume 1: In Debatable Lands. Bristol: Wild Conversations.

Bloch, Ernst

1978 Das Prinzip Hoffnung. Frankfurt/Main: Suhrkamp.

Borgolte, Michael

2005 Wie Europa seine Vielfalt fand. Über die mittelalterlichen Wurzeln für die Pluralität der Werte. In: Joas, Hans and Klaus Wiegandt (eds.), Die kulturellen Werte Europas. Frankfurt/Main: Fischer, 117-163.

Canetti, Elias

1999 The Tongue Set Free: Remembrance of a European Childhood. London: Granta.

Deffenbaugh, Daniel

2006 Learning the Language of the Fields: Tilling and Keeping as Christian Vocation. Cambridge/MA: Cowley.

Europäische Visionen

2004 Europäische Visionen: 25 Filme, 25 Regisseure. Zentropa.

Europäischer Austausch gGmbH

www.european-exchange.org; accessed 29 January 2008.

Eurovisionen - Vom kulturellen Netzwerk zur Politik

www.goethe.de/ins/vb/prj/euro/; accessed 5 February 2008.

Frevert, Ute

2003 Eurovisionen: Ansichten guter Europäer im 19. und 20. Jahrhundert. Frankfurt/Main: Fischer.

Hecht, Martin

2000 Das Verschwinden der Heimat: Zur Gefühlslage der Nation. Leipzig: Reclam.

Ivakhiv, Adrian

2006 Stoking the Heart of (a Certain) Europe: Crafting Hybrid Identities in the Ukraine-EU Borderlands. Spaces of Identity 6 (1): 11-44.

Kiberd, Declan

2005 The Irish Writer and the World. Cambridge: Cambridge University Press.

Kockel, Ullrich

1995 The Celtic Quest: Beuys as Hero and Hedge School Master. In: Thistlewood, David (ed.), Joseph Beuys: Diverging Critiques. Liverpool: Tate Gallery and Liverpool University Press, 129-147.

1999 Borderline Cases: The Ethnic Frontiers of European Integration. Liverpool: Liverpool University Press.

2003a EuroVisions: Journeys to the Heart of a Lost Continent. Journal of Contemporary European Studies 11 (1): 53-66.

2003b Heimat als Widerständigkeit: Beobachtungen in einem Europa freischwebender Regionen. In: Götsch, Silke and Christel Köhle-Hezinger (eds.), Komplexe Welt: Kulturelle Ordnungssysteme als Orientierung. Münster: Waxmann, 167-176.

2005 Frontiers. In: Welz, Gisela and Ramona Lenz (eds.), Von Alltagswelt bis Wandmalerei: Eine kleine Enzyklopädie: Ina-Maria Greverus zum Fünfundsiebzigsten. Münster: LIT, 62-63. 
2007 Heritage versus Tradition: Cultural Resources for a New Europe? In: Demossier, Marion (ed.), The European Puzzle: The Political Structuring of Cultural Identities at a Time of Transition. Oxford and New York: Berghahn, 85-101.

2008 Putting the Folk in Their Place: Tradition, Ecology and the Public Role of Ethnology. Anthropological Journal of European Cultures 17 (1): 5-23.

Krockow, Christian

1992 Heimat: Erfahrungen mit einem deutschen Thema. München: Deutscher Taschenbuchverlag.

Kundera, Milan

1990 Croi na hEorpa. Baile Átha Cliath: Coiscéim.

Lepenies, Wolf

2006 Kultur und Politik: Deutsche Geschichten. München: Hanser.

Nic Craith, Máiréad and Ullrich Kockel (eds.)

2007 Cultural Heritages as Reflexive Traditions. Basingstoke: Palgrave.

Pollack, Martin (ed.)

2005 Sarmatische Landschaften: Nachrichten aus Litauen, Belarus, der Ukraine, Polen und Deutschland. Frankfurt/Main: Fischer.

Schlink, Bernhard

2000 Heimat als Utopie. Frankfurt/Main: Suhrkamp.

Schmidt, Armin (ed.)

1994 Die Kurische Nehrung: Ostpreußische Dichter erzählen. Husum: Husum.

Schmidt, Burghart

1994 Am Jenseits zur Heimat: Gegen die Utopiefeindlichkeit im Dekonstruktiven. Darmstadt: Wissenschaftliche Buchgesellschaft.

Sontag, Susan

2003 The Idea of Europe (One More Elegy). In: Where the Stress Falls. London: Vintage, 285-289.

Trepte, Hans-Christian

2004 Das Problem der "Hiesigen” (tutejsi) im polnisch-weißrussischen Grenzraum. In: Krynki: Annus Albaruthenus, 67-87.

Türcke, Christoph

2006 Heimat: Eine Rehabilitierung. Springe: Klampen.

Venclova, Tomas

2006 Vilnius: Eine Stadt in Europa. Frankfurt/Main: Suhrkamp. 


\section{PRITI DOMOV V EVROPO. POTOVANJA IN POPOTOVANJA PO ZGUBLJENI CELINI}

Evropa - toda kje je? Bil je nekoč kraj, imenovan "Evropa«. Francozi in Nemci pričakujejo, da je Evropa kraj, kjer lahko živijo skupaj v miru. Zamisel o "evropskih pogledih", "pogledih Evrope ali »evrovizijah" je popularna že nekaj časa. Vsaka historična upodobitev Evrope je konstrukt, ki zdrži le, če sprejmemo njegova izhodišča. Evropo je mogoče na hitro vrteči se krogli preprosto spregledati. Zaradi kolonialne ekspanzije v preteklosti je v določenem smislu Evropa povsod. Evropa se je začela tam, kjer se je končalo Turško cesarstvo. Ali ni Evropa, če je kdaj živela, že davno umrla? Razprave o Srednji Evropi tečejo v ciklih živahnosti in zaspanosti. Identiteto območja je mogoče tesno povezati s kulturo štetlov. Vendar razglasiti Evropo za mrtvo zaradi holokavsta pomeni, da zavračamo ukvarjanje s temno stranjo evropske kulturne dediščine.

Susan Sontag je opozorila, da je Evropa daleč od tega, da bi bila mrtva, ampak se mora pravzaprav šele roditi. Evropa obstaja, čeprav je pozna ali post-moderna učinkovito razgalila naše udobne gotovosti. Zakrita $v$ meglico diskurzov je ta Evropa zdaj skoraj nespoznavna. Postala je ne-kraj. Glavni izraz za razumevanje Evrope je "meja ". Njeno značilnost določa - v dvojnem pomenu besede - v notranjosti Sebe. Vnemško govoreči Evropi, in deloma tudi prek njenih mej, je vsaj od konca 80. let prejšnjega stoletja problem Heimat (dom, domovina) predmet izjemnega diskurzivnega odmeva. Podobno kakor razprave o Heimat tudi tiste o dediščini napajajo in obnavljajo vprašanja pripadnosti in odtujitve območno zasnovanih (v na pol dobesednem smislu) kulturnih kontekstov. "Priti domov" se lahko nanaša na spreminjanje sveta $v$ dom - tj., da posebno različico sveta napolnimo z vzorci pomenov, ki ustvarjajo avtentično pripadnost in, mogoče, celo občutek skupnosti, ki hkrati utemeljuje in presega vsako posamično identiteto.

Vzgodovinskem smislu izraz 'sporna ozemlja' označuje območja sporne suverenosti ob angleško-škotski meji. "Ne-klasična" Evropa se razteza vzhodno od keltskega roba, kolikor daleč pač seže, in vključuje tiste dele, od koder je bil konj kralja Arturja, kakor pravijo nekatere pripovedi. Sarmatija je ena izmed zgubljenih provinc Evrope; nekdaj je bila njeno središče. Nerazločljivo povezana s kulturo štetlov v vzhodnem delu Srednje Evrope, je bila in je širše območje in sporno ozemlje. Na severu Sarmatije želi današnja Litva poudariti, da je bila zadnja pokristjanjena dežela v Evropi. Leta 2004 je francosko-nemška televizijska družba Arte filmarjem iz vsake novo pridružene članice Evropske unije naročila izdelavo kratkih filmov s predstavitvijo njihovih pogledov na Evropo. Najbolj monokromatičen film (iz Litve) prikazuje štiri otroke, ki sanjajo o naravi, zgodovini in kraju. Kaj nam to pove o Stari Evropi? Nemški del Železne zavese, poznan kot Zonengrenze, je bil prvi element v večplastni sestavi spornih dežel, obsegal je zgubljena ozemlja in »jezikovne otoke« na vzhodu, ki so predstavljali referenčni okvir za nemško identiteto po letu 1945 na obeh straneh železne zavese.

Po Donaldu Rumsfeldu imamo Novo Evropo in Staro Evropo - prva je pripravljena kupiti ameriško poslanstvo samoodrešitve sveta, druga premišlja povsem po svoje. Gre za eksplicitno 
povezavo z "zelo staro", "kvazipogansko" Evropo. Ali obstaja način, da jo povežemo s Staro Evropo«? Če najdemo pot iz te dileme, bomo morda sposobni zahtevati premaknjeno deželo Evrope stem, da jo nadomestimo. To utegne vsebovati nekakšno preusmeritev-pre-vzhodnjenje - tega, kar pomeni biti evropski.

Prof. Dr. Ullrich Kockel, Academy for Irish Cultural Heritages, University of Ulster, Derry, Northern Ireland, u.kockel@ulster. ac.uk 